\title{
ERRATA
}

\section{Reductive Dehalogenation of Chlorinated Benzenes and Toluenes under Methanogenic Conditions}

\author{
K. RAMANAND, M. T. BALBA, AND J. DUFFY \\ TreaTek-CRA Company and Occidental Chemical Corporation, \\ 2801 Long Road, Grand Island, New York 14072
}

Volume 59, no. 10, p. 3270, Discussion, line 16: “CB” should read "chlorinated benzenes." Page 3271, column 1, line 9: “1,2,3-TCB”" should read "1,3,5-TCB."

Line 17: "during CB metabolism" should read "during metabolism of chlorinated benzenes."

\section{Cloning and Sequence Analysis of the meso-Diaminopimelate Decarboxylase Gene from Bacillus methanolicus MGA3 and Comparison to Other Decarboxylase Genes}

\author{
DAVID A. MILLS AND MICHAEL FLICKINGER
}

Department of Biochemistry and Institute for Advanced Studies in Biological Process Technology, 240 Gortner Laboratories, 1479 Gortner Avenue, University of Minnesota, St. Paul, Minnesota 55108

Volume 9, no. 9, p. 2935, column 2, line 8: “region 2" should read “region 1."

\section{Mobile Bacteria and Transport of Polynuclear Aromatic Hydrocarbons in Porous Media}

MICHAEL B. JENKINS AND LEONARD W. LION

School of Civil and Environmental Engineering, Cornell University, Ithaca, New York 14853

Volume 59, no. 10, p. 3311, column 1: Figure 3 should appear as shown below. Figure 3 contained an error in the plot of the data set for phenanthrene without cells (๑). A corrected plot is shown below. All previously reported $R$ values are correct. The conclusions regarding the enhanced transport of phenanthrene in the presence of mobile cells are not altered by this change.

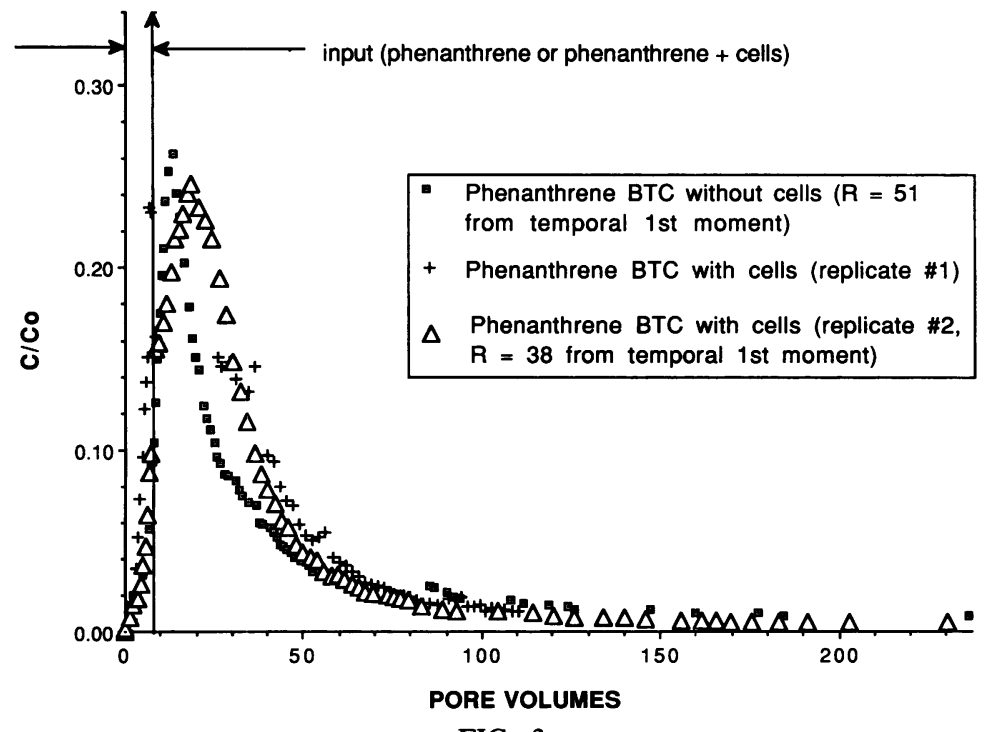

FIG. 3 